University of Pennsylvania Carey Law School

Penn Carey Law: Legal Scholarship Repository

Faculty Scholarship at Penn Carey Law

4-5-2021

\title{
The "Value" of a Public Benefit Corporation
}

Jill E. Fisch

University of Pennsylvania Law School

Steven Davidoff Solomon

Berkeley Law

Follow this and additional works at: https://scholarship.law.upenn.edu/faculty_scholarship

Part of the Accounting Law Commons, Business Law, Public Responsibility, and Ethics Commons, Business Organizations Law Commons, Law and Economics Commons, Law and Society Commons, and the Strategic Management Policy Commons

\section{Repository Citation}

Fisch, Jill E. and Davidoff Solomon, Steven, "The "Value" of a Public Benefit Corporation" (2021). Faculty Scholarship at Penn Carey Law. 2225.

https://scholarship.law.upenn.edu/faculty_scholarship/2225

This Book Chapter is brought to you for free and open access by Penn Carey Law: Legal Scholarship Repository. It has been accepted for inclusion in Faculty Scholarship at Penn Carey Law by an authorized administrator of Penn Carey Law: Legal Scholarship Repository. For more information, please contact PennlawIR@law.upenn.edu. 


\title{
THE "VALUE" OF A \\ Public BenEFIT CORPORATION
}

\author{
JiLl E. Fisch \& STEVen DAVIdoff SOlomon* \\ Forthcoming in Research Handbook on Corporate Purpose and Personhood \\ (Elizabeth Pollman \& Robert B. Thompson, eds., Elgar)
}

\author{
April 14, 2021 Draft
}

\section{Introduction}

The Public Benefit Corporation ("PBC") is a new corporate form that allows the corporation to identify its objectives in terms of broader social or environmental responsibility rather than focusing exclusively on profit maximization. The specific requirements and attributes of the PBC vary from state to state, but a substantial number of PBCs -- particularly those that have received venture funding and all four PBCs that are currently publicly traded -- are formed under the Delaware PBC statute. ${ }^{1}$ In August 2020, Delaware amended its statute to make it easier for existing PBCs to convert back to traditional corporations (and vice-versa). ${ }^{2}$ The amendment and the increased freedom it provides to shareholders to adopt or abandon the PBC form raise the question of what value the PBC statute provides to a corporation and whether the benefits of the $\mathrm{PBC}$ can be maintained in a publicly-traded company.

This chapter takes up that question and evaluates the potential value that the PBC form offers for publicly-traded companies that want to adopt a social purpose or a stakeholder orientation. $^{3} \quad$ Drawing upon our other work on corporate purpose, we focus in particular on the claim that the election of PBC status provides a meaningful difference in either the structure of the corporation or the legal constraints on corporate decision-makers. ${ }^{4}$ We review the relevant PBC statutes, particularly the Delaware PBC statute, ${ }^{5}$ to determine whether the $\mathrm{PBC}$ form provides a

\footnotetext{
* Jill E. Fisch is the Saul A. Fox Distinguished Professor of Business Law at the University of Pennsylvania Law School; Steven Davidoff Solomon is Professor of Law at the University of California Berkeley, School of Law. We are grateful for helpful comments from Elizabeth Pollman, Robert Thompson, and all of the participants in the colloquium associated with this Research Handbook.

${ }^{1}$ See generally Michael B. Dorff, Why Public Benefit Corporations?, 42 Del. J. Corp. L. 77 (2017). In some other states the $\mathrm{PBC}$ is simply known as a benefit corporation but the form and goals are similar.

2 An Act To Amend Title 8 of the Delaware Code Relating to the General Corporation Law, House Bill $341,150^{\text {th }}$ General Assembly, signed Jul. 16, 2020, at $\$ 17$. The statute simultaneously made it easier for traditional corporations to convert to the PBC form.

${ }^{3}$ The issue is particularly salient in light of the emergence of shareholder proposals requesting traditional corporations to convert to PBCs. See The Shareholder Commons, Beta Steward: The Shareholder Commons Voting Guide (Mar. 17, 2021) https://theshareholdercommons.com/wp-content/uploads/2021/03/Beta-Steward-March-17.pdf, (describing the introduction of such shareholder proposals at companies that include Bank of America, Chevron and 3M ).

4 Jill Fisch \& Steven Davidoff Solomon, Should Corporations Have a Purpose?, _ TEX. L. REV. __ (forthcoming 2021).

5 The term PBC is specific to the Delaware legislation. Most states and the Model Business Corporation Act use the term "benefit corporation." Although we focus here on the Delaware statute, we note that the requirements of benefit corporation statutes vary substantially. See, e.g., Roxanne Thorelli, Note: Providing Clarity for Standard of Conduct for Directors Within
} 
realistic mechanism for shifting away from the shareholder primacy norm in favor of stakeholder governance. We conclude that it does not; rather, we conclude that the PBC preserves the shareholder primacy norm by vesting shareholders - as in the traditional corporation --- with ultimate power and control over the PBC and the implementation of its purpose. As a result, the PBC's commitment to social purpose is only as strong as the willingness of its shareholders to prioritize social value in addition to or at the expense of profit. In addition, the statutory structure imposes substantial limits on shareholders' ability to use litigation to hold corporate decisionmakers accountable, limits greater than those in the traditional corporation. As a result, while the selection of the PBC form may signal a desire of corporate participants to commit to social purpose, we question its effectiveness as a commitment device.

We go on to explore the manner in which PBCs articulate their social purpose. We collect a sample of the most economically significant PBCs and examine the purpose statements in their charters. We find that, independent of structural limitations on accountability, these purpose statements are, in most cases, too vague and aspirational to be legally significant, or even to serve as a reliable tool for evaluating whether corporate decisionmakers are adhering to the PBC's social mission. We note that this concern is similar to that which plagues efforts to "repurpose" the traditional corporation to promote the interests of stakeholders. ${ }^{6}$

The continued importance of shareholder primacy for PBCs coupled with the vagueness of their articulated purposes raise two concerns. As we have highlighted in prior work, every corporation specifies a corporate purpose in its charter. ${ }^{7}$ But if the specified corporate purpose is vague, aspirational or undefined, then it is effectively unenforceable. ${ }^{8}$ In such a case, the shareholder primacy oriented structure of the corporation, as well as market pressure for publiclytraded PBCs, steer the direction of the company. ${ }^{9}$ As we highlight in this Chapter, despite being portrayed as instruments to implement stakeholder governance, PBCs have the same mechanisms of shareholder control as a traditional corporation - shareholder power to elect the board and shareholder power to impose capital market discipline. A vague purpose constrains neither manager or shareholder authority, leaving the PBC subject to purpose drift, opportunism, or a shift in shareholder priorities. Without a legal or structural tool for binding a PBC to specific social objectives, the operational decisions of the publicly traded PBC may be subject to change according to the vision and preferences of individual officers, directors and shareholders.

We highlight these concerns by discussing specific examples. One such example is Etsy which started as a publicly-traded B-Corp. with an espoused intent to become a PBC. When Etsy failed to meet earnings targets, it was targeted by shareholder activists and forced to abandon its B-Corp identification and PBC goal. ${ }^{10}$ We also discuss Unilever's purchase of Ben \& Jerry's, one

\footnotetext{
Benefit Corporations: Requiring Priority of a Specific Public Benefit, 101 MinN. L. REV. 1749, 1767-1770 (2017) (describing variation in the requirement that the corporation artriculate a public benefit and the impact of such articulation on directors' duties).

${ }^{6}$ Fisch \& Solomon, supra note 4 (manucript. at 12-15).

${ }^{7}$ Id.

${ }^{8} I d$. at $14-15$.

${ }^{9}$ See Leo Strine, Corporate Power is Corporate Purpose I: Evidence from My Hometown, 33(2) OXFORD REv. OF ECON. POL. 176 (2017) (arguing that stockholder power translates into shareholder primacy as corporate purpose).

10 See David Gelles, Inside the Revolution at Etsy, N.Y. Times, Nov. 25, 2017, at B1.
} 
of the first pioneering socially-oriented companies, and the changes in Ben \& Jerry's mission that resulted from this purchase.

Our findings have practical implications for the PBC debate. First, we question whether adoption of the PBC form is a viable tool for forcing "bad" corporations to act in a more socially responsible manner. Some commentators advocate mandatory PBCs for certain categories of publicly-traded companies, ${ }^{11}$ and some shareholders are seeking to implement this approach through shareholder proposals requesting or requiring companies to convert to PBCs. ${ }^{12}$ Although these proposals seem to view the PBC as a means of compelling corporations to operate in a manner that incorporates societal or public interests, they are likely overstating the effect of such a requirement. ${ }^{13}$ We question how the formal PBC designation will result in any operational change at companies that lack an independent commitment by existing shareholders to social purpose.

Second, our findings suggest the value of a more rigorous PBC model. We argue that a $\mathrm{PBC}$ could be required to specifically designate a formal purpose which is capable of assessment and implementation. Such a model would enable shareholders to make a meaningful commitment as well as addressing allocational issues and priorities among competing social values. ${ }^{14}$ We posit that such a structure would include meaningful limitations on a PBC's ability to convert back to an ordinary corporation. Finally we observe that existing PBC statutes impose significant constraints on holding PBCs accountable to their identified social purpose and identify potential mechanisms for increasing accountability.

The Chapter proceeds as follows. In Part I, we briefly describe the PBC and situate PBCs in the current debate over corporate purpose, delineating how PBC statutes purport to facilitate the pursuit by corporations of multiple purposes. ${ }^{15}$ Part II situates the PBC framework within traditional concepts of shareholder control and argues that, contrary to the claims of some commentators, the PBC reinforces the shareholder primacy norm. Part III examines and analyzes current use of the PBC form, focusing on PBCs' legal statements of purpose. We highlight the fact that many of the largest and most visible PBCs have adopted vague and aspirational statements

\footnotetext{
${ }^{11}$ Leo E. Strine Jr \& Dorothy S. Lund, How to restore strength and fairness to our economy, N.Y. TIMES DEALBOOK, Apr. 10, 2020, available at https://www.nytimes.com/2020/04/10/business/dealbook/coronavirus-corporate-governance.html (last accessed Sept. 15, 2020) ("Public and large private companies receiving bailouts or pandemic-related subsidies could be required to become public benefit corporations under state law, and others could be given positive incentives to do the same.")

12 The Shareholder Commons, supra note 3.

13 See Chevron Corporation - 2021 Proxy Statement at 85 (Apr. 8, 2021), https://www.chevron.com/-/media/sharedmedia/documents/chevron-proxy-statement-2021.pdf (stating that, in light of Chevron's failure to "embrace sustainability practices" it convert to a PBC to "enable the company to operate in a responsible and sustainable manner that balances the stockholder's pecuniary interests, and the best interests of those materially affected by the corporation's conduct.").

${ }^{14}$ We note that existing statutes also create ambiguity about directors' obligations in connection with the PBC's purpose. See, e.g., Thorelli, supra note 5 at 1771-72 (identifying ambiguity about whether directors should "consider" or "balance" stakeholder interests and whether directors" actions should evaluating according to whether they "pursue" or "accomplish" the designated objectives).

${ }^{15} \mathrm{PBC}$ statutes differ in their approach. Delaware requires a $\mathrm{PBC}$ to identify a specific public benefit as a component of the corporation's purpose. Many other PBC statutes require a PBC to pursue a general public benefit, which typically is defined as a "material positive impact on society and the environment as a whole." Some states do both, enabling corporations to specify a specific public benefit but also requiring that the PBC serve the general public interest. See Lyman Johnson, Managerial Duties in Social Enterprise: The Public Benefit Corporation, The CAMBridge HandBook of Social EnTERPrise LAw, AT 505-512 (B. MEANS \& J. YOCKEY, EDS. 2018).
} 
of social purpose. Part IV explains why both shareholder primacy and the absence of meaningful statements of purpose undercut the publicly-traded PBCs ability to make a meaningful commitment, and we posit that the absence of such a commitment potentially undermines the value of the PBC form. We conclude by proposing a more definable purpose in publicly-traded PBCs in order to fulfill the PBC's potential and identifying structural changes that can aid in making such a purpose statement enforceable. ${ }^{16}$

\section{The Public Benefit Corporation}

\section{A. Background}

PBCs are a relatively recent innovation, designed by state statutes to solve the shareholder primacy dilemma by enabling a corporation to choose explicitly to pursue societal or stakeholder interests rather than focusing primarily or exclusively on shareholder economic value. ${ }^{17}$ Although the precise scope of purposes that may be pursued through a PBC as well as the resulting obligations imposed on corporate decisionmakers vary substantially depending on the applicable statute, the core rationale for the PBC form is that it allows a corporation simultaneously to pursue both economic profits and social benefits.

A private organization known as B Lab was the driving force behind benefit corporation statutes. ${ }^{18}$ B Lab drafted a model statute and urged state legislatures to adopt it. ${ }^{19}$ Maryland adopted the first benefit corporation statute in 2010, and today thirty-eight have adopted some variation of a benefit corporation statute. ${ }^{20}$ Although there is a fair degree of variation among the statutes, ${ }^{21}$ they share the common objective of creating a vehicle for social enterprise that is situated somewhere between a traditional for-profit corporation and a non-profit. Specifically, benefit corporations are designed to permit corporations and their boards to reject economic

\footnotetext{
${ }^{16}$ See Frederick Alexander, Putting Benefit Corporation Statutes into Context by Putting Context into the Statutes, 76 Bus. LAW. _ (forthcoming 2020) ("if, as this paper argues, the concept of benefit governance can (and should) be used more broadly to

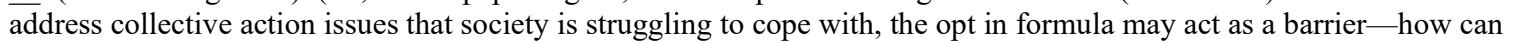
corporations address collective issues if only some are programmed to do so, while others continue to be programmed to graze the commons and perpetuate unfairness if those practices lead to the highest financial return on their equity?")

17 As Brett McDonnell observes, the extent to which rationale, which he terms the "enabling justification" is necessary is unclear, at least in states with constitutency statutes. See Brett McDonnell, The Corrosion Critique of Benefit Corporations, Sept. 8, 2019, https://papers.ssrn.com/sol3/papers.cfm?abstract_id=3450747, manuscript at 22-23.

${ }^{18} \mathrm{Id}$. at 3 ("The initial efforts at drafting and advocating for benefit corporations laws were undertaken by B Lab, a nonprofit entity based in Pennsylvania.").

${ }^{19}$ B Lab's draft statute was the Model Benefit Corporation Law. See The NeEd And Rationale For The Benefit Corporation: Why It Is The Legal Form That Best Addresses The NeEds Of Social Entrepreneurs, Investors, And, Ultimately, The Public (Jan. 18, 2013), available at https://benefitcorp.net/sites/default/files/Benefit Corporation White Paper.pdf (describing the model law). Initiative for the benefit corporation may also have stemmed from the Delaware Chancery Court's decision in eBay Domestic Holdings, Inc. v. Newmark, 16 A.3d 1 (2010). See Johnson, supra note 15.

${ }^{20}$ Frederick Alexander, et al., From Shareholder Primacy to Stakeholder Capitalism A Policy Agenda for Systems Change, Sept. 7, 2020, at 7, https://theshareholdercommons.com/wp-content/uploads/2020/09/From-Shareholder-Primacy-to-StakeholderCapitalism-TSC-and-B-Lab-White-Paper.pdf. See also Dan Brown, Hanna Downing, Ava Haghighi, \& Carolina HenriquezSchmitz, Mapping the State of Social Enterprise and the Law (2018-2019), available at https://socentlawtracker.org/wpcontent/uploads/2019/05/Grunin-TepperReport_5_30_B.pdf (Last accessed March 20, 2020) (counting thirty-five states in the U.S. and the District of Columbia as having adopted benefit corporation statutes or social purpose corporation statutes).

${ }^{21}$ See Alexander, supra note 16, at 4-16 (describing differences between the Model Benefit Corporation Law, the Delaware Public Benefit Corporation Statute, the ABA Model Benefit Corporation Act, and the statutes adopted by several non-U.S. jurisdictions).
} 
stockholder value as the corporation's exclusive objective in favor of some form of stakeholder or societal value. ${ }^{22}$ They do so by redefining the pursuit of the corporation's identified social purpose as an action in the best interests of the corporation. ${ }^{23}$

The PBC business form is seeing increasing adoption though it is still far from ubiquitous. In the last year, the number of PBCs formed under these statutes has doubled to over $10,000 .{ }^{24}$ In addition, as one of the co-authors of this Article has documented elsewhere, PBCs regularly draw in significant investment from venture capital and other funds. ${ }^{25}$ This investment is a sign of the PBC's growing acceptance in the financial world, including in the IPO market.

There are currently four publicly-traded PBCs. The first Laureate Education, is a privateequity sponsored for-profit provider of higher education, and it went public in 2017. Recently, Lemonade made headlines both by going public as a PBC and by becoming 2020's best IPO debut, with its stock closing up 139\% after the first day of trading. In the wake of Lemonade Vital Farms, Inc. also went public as a PBC. ${ }^{26}$ The fourth -- Veeva Systems -- recently converted to a PBC becoming the first Russell 1000 company to be a PBC. ${ }^{27}$ As we noted in the introduction, recent changes in Delaware corporate law that allow a corporation to freely convert to a PBC by amending its charter with the approval of the board of directors and a simple majority of outstanding shares are expected to further encourage publicly-traded companies to adopt the PBC form. ${ }^{28}$ A second reason for the expected rise in publicly traded PBCs is renewed calls for stakeholder capitalism, a movement we take up in the next subsection.

\section{B. The PBC as a Vehicle for Stakeholder Capitalism}

Calls for publicly-traded corporations to embrace stakeholder capitalism, in which officers and directors consider - or even privilege - the interests of stakeholders over those of shareholders have swept the world. ${ }^{29}$ The demand that corporations adopt a new and enlightened corporate purpose that serves the interests of stakeholders and the general public is reflected in policy statements by a number of influential organizations. Perhaps the most prominent statement came from the Business Roundtable, which made international headlines ${ }^{30}$ when it issued a statement in

\footnotetext{
${ }^{22}$ Notably, PBCs provide for but do not maximize or privilege pecuniary gain for shareholders. See Johnson, supra note 15 , at 504-5.

${ }^{23}$ In that regard, the PBC is different from the certified B corporation, a standard-setting organization that provides guidelines with which corporations can voluntarily choose to comply.

${ }^{24}$ Alexander, et al., supra note 20.

${ }^{25}$ See Michael Dorff, James Hicks, \& Steven Davidoff Solomon, The Future or Fancy? An Empirical Study of Public Benefit Corporations, HARV. Bus L. REV. (forthcoming 2020).

${ }^{26}$ See Vital Farms, Inc., Registration Statement on Form S-1, dated. July 9, 2020.

${ }^{27}$ See Press Release, Veeva Becomes First Public Company to Convert to a Public Benefit Corporation, Jan. 13, 2021, available at https://www.veeva.com/resources/veeva-becomes-first-public-company-to-convert-to-a-public-benefit-corporation/.

${ }^{28}$ See Potter Anderson Corroon, LLP, Delaware Makes it Easier for Corporations to Become Public Benefit Corporations, Jul. 20, 2020, available at https://www.potteranderson.com/newsroom-news-Delaware-Makes-it-Easier-for-Corporations-to-BecomePublic-Benefit-Corporations.html (last accessed (Oct. 1, 2020).

${ }^{29}$ See Richard Samans \& Jane Nelson, Taking stakeholder capitalism from principle to practice, World Economic Forum, Jan. 20, 2020, available at https:/www.weforum.org/agenda/2020/01/stakeholder-capitalism-principle-practice-better-business/ (citing a range of organizations and regulatory frameworks that have embraced stakeholder capitalism).

${ }^{30}$ See, e.g., Jim Ludema \& Amber Johnson, The Purpose Of The Corporation? Business Roundtable Advances The Conversation, Now We All Need To Contribute, ForBES, Aug. 20, 2019, available at https://www.forbes.com/sites/amberjohnsonjimludema/2019/08/20/the-purpose-of-the-corporation/\#25c6fd5b3846; Group of US corporate leaders ditch shareholder first mantra, THE Fin. Times, Aug. 19, 2019, available at https:/www.ft.com/content/e21a9fac-c1f5-11e9-a8e9-296ca66511c9
} 
August 2019 replacing its former endorsement of shareholder primacy with the proposition that publicly traded corporations adopt a purpose pledging to be run for the benefit of all stakeholders - customers, employees, suppliers, communities and shareholders." ${ }^{\prime 1}$

The dislocations and inequalities highlighted by the coronavirus pandemic have heightened the demand for corporate governance to respond, and many commentators view stakeholder capitalism for publicly traded companies as a productive way of increasing attention to the needs of a broader swarth of societal interests. ${ }^{32}$ Commentators frequently identify PBCs as a tool that enables corporations to commit publicly to the values behind stakeholder governance.. ${ }^{33}$ Brett McDonnell for example has explained that a PBC can serve two distinct functions: 1) enabling corporate decisionmakers broader flexibility to consider nonshareholder interests and 2) branding the corporation as one committed to stakeholder and societal interest. ${ }^{34}$ We note that the latter justification is not a legal one, but more akin to a non-binding mission statement.

Although we have questioned elsewhere the extent to which shareholder primacy is a legal mandate, ${ }^{35}$ PBC statutes explicitly reject the proposition that the corporation's best interests are defined exclusively in terms of shareholder economic wealth. In addition many PBC statutes expressly direct corporate decisionmakers to consider the interests of non-shareholder stakeholders. Delaware's statute, for example, requires the corporation to be managed in a manner that balances shareholders' pecuniary interests with "the best interests of those materially affected by the corporation's conduct." 36 The Model Benefit Corporation Act requires directors to "consider, to the extent affected, in addition to the interests of shareholders generally, the separate interests of stakeholders known to be affected by the business of the corporation." ${ }^{37}$ Similarly the Pennsylvania statute requires directors of a benefit corporation to consider the effects of their actions on the various corporate stakeholders including shareholders, customers, employees and the community. ${ }^{38}$

The availability of the PBC form as a vehicle for stakeholder capitalism has its greatest potential impact in the publicly-traded corporation. ${ }^{39}$ Many private companies have a controlling

\footnotetext{
${ }^{31}$ See Business Roundtable, Business Roundtable Redefines the Purpose of a Corporation to Promote 'An Economy That Serves All Americans', Aug. 19, 2019, available at https://www.businessroundtable.org/business-roundtable-redefines-the-purpose-of-acorporation-to-promote-an-economy-that-serves-all-americans.

${ }^{32}$ Peter Geogescu, The Aspirations For Stakeholder Capitalism Must Be Very, Very High, ForBes, Jun. 10, 2020, https://www.forbes.com/sites/justcapital/2020/06/10/the-aspirations-for-stakeholder-capitalism-must-be-very-veryhigh/\#6b3e8aaa73e1; https://www.businessinsider.com/b-lab-cofounder-talks-coronavirus-and-stakeholder-capitalism-2020-3

${ }^{33}$ See, e.g., J. Haskell Murray, Defending Patagonia: Mergers and Acquisitions with Benefit Corporations, 9 HASTINGs Bus. L.J. 485, 493-494 (2013) (explaining that benefit corporation legislation provides "that the purpose of a benefit corporation is not shareholder wealth maximization but rather a "general public benefit.").

34 McDonnell, supra note 17.

${ }^{35}$ See Fisch \& Davidoff, supra note 4, at 115-123.

36 D.G.C.L. $\$ 262$ (a).

37 M.B.C.A. $\$ 18.04$.

38 PA $\$ 3321$.

${ }^{39}$ In the private corporation, the company can generally reflect the values of its small group of shareholders. Thus, Hobby Lobby and Chick-Fil-a can implement religious values by closing on Sundays and craigslist can deliberately limit profits. As the use of the PBC potentially expands to public companies, the legal effects and consequences of PBC status may differ significantly, a distinction which has yet to receive significant analysis outside this Article.
} 
stockholder or a control group that is committed to an identified social purpose. ${ }^{40}$ The challenge for them is how to retain that commitment when the company goes public and shareholders become more dispersed. Although, as noted above, there are currently only four publicly-traded PBCs. One question is whether the PBC form is a viable tool for insulating a corporation from pressure to forsake its public purpose when it enters the public markets. Notably, the existing publiclytraded PBCs may not fully address this question to the extent they have controlling shareholders or dual class voting structures that provide a degree of insultation from the interests of public shareholders and the PBC form may allow for additional rent-seeking by the controlling shareholders. ${ }^{41}$ Accordingly, the ability to extrapolate the experience of the four publicly-traded PBCs to public companies with dispersed ownership may be limited.

Nonetheless, traditional corporations are facing pressure to reconsider their missions and to commit to a socially-oriented or stakeholder purpose. Although we have questioned whether the PBC form is necessary for a corporation to do so, conversion clearly signals the corporation's desire to be governed by a different standard. ${ }^{42}$ In the next section we analyze the PBC structure to see if it supports these objectives in the publicly-traded company.

\section{The PBC and Shareholder Primacy}

Although the statutes expressly authorize or require PBCs to consider stakeholder or societal interests in addition to those of shareholders, they do not revise either the power structure or the decisionmaking apparatus of the traditional corporation. Rather, the PBC statutes in their current form retain the identical role for shareholders as in the traditional publicly-traded corporation. As a result, the same dynamics and forces that shape a traditional publicly traded corporation's mission and purpose are likely to affect the publicly traded PBC.

Delaware's PBC statute is illustrative of the powers and rights of a PBC's shareholders. A significant number of venture-funded PBCs have formed under the Delaware statute, ${ }^{43}$ and the Delaware statute is likely to be the one chosen by public companies that decide to be PBCs. ${ }^{44}$ It is therefore worthwhile to focus on the Delaware statute in particular. In Delaware, as in most states, the PBC provisions are part of the general corporation law. Delaware's PBC provisions consist of eight sections. ${ }^{45}$ Apart from these sections, the general provisions of the DGCL apply. ${ }^{46}$

\footnotetext{
40 See, e.g., Justin Blount \& Kwabena Offei-Danso, The Benefit Corporation: A Questionable Solution to a Non-Existent Problem, 44 ST. MARY's L. J. 617, 668-669 (2013) (citing examples of companies that use their capital structures to ensure that founders or like-minded investors can maintain their commitment to the corporation's social mission).

${ }^{41}$ We note that Veeva's dual class voting structure, for example, vests control in its CEO and founder, Peter Gassner. Laureate Education has a dual class voting structure. Although Lemonade and Vital Health do not have dual class structures, their IPO investors retained substantial stakes when the companies went public and their control is protected, to a degree by classified board structures. Alexa Belonick, Susan H. Mac Cormac \& Alfredo B. D. Silva, Morrison \& Foerster Discusses Publicly Traded Public Benefit Corporations, The CLS Blue Sky Blog, Sept. 16, 2020, https://clsbluesky.law.columbia.edu/2020/09/16/morrison-foerster-discusses-publicly-traded-public-benefit-corporations/.

42 See Fisch \& Davidoff, supra note 4, at 132.

${ }^{43}$ See Dorff et al., supra note 25.

${ }^{44}$ All three PBCs which have gone public Laureate Education, Lemonade and Vital Farms have all done so as Delaware incorporated PBCs. Similarly Veeva converted to a Delaware PBC.

${ }^{45}$ See D.G.C.L. $\S \S 361-368$.

${ }^{46}$ The net effect is to preserve the substantial shareholder rights which exist in the traditional corporation without significant deviation.
} 
Chart A compares the statutory control rights of shareholders in a PBC, shareholders in a traditional corporation, and other PBC stakeholders:

Chart A: Comparison of Shareholders Rights in PBCs and Traditional Corporations

\begin{tabular}{|l|l|l|l|}
\hline & $\begin{array}{l}\text { Traditional } \\
\text { Shareholders }\end{array}$ & PBC Shareholders & $\begin{array}{l}\text { Other PBC } \\
\text { Stakeholders }\end{array}$ \\
\hline $\begin{array}{l}\text { Election of PBC } \\
\text { Status }\end{array}$ & Yes & Yes & No \\
\hline $\begin{array}{l}\text { Elimination of PBC } \\
\text { Status }\end{array}$ & Yes & Yes & No \\
\hline Election of Directors & Yes & Yes & No \\
\hline Removal of Directors & Yes & Yes & No \\
\hline $\begin{array}{l}\text { Merger or Sale of } \\
\text { ALL or Substantially } \\
\text { All of the Assets }\end{array}$ & Yes & Yes & No \\
\hline $\begin{array}{l}\text { Amendment of } \\
\text { Charter }\end{array}$ & Yes & Yes & No \\
\hline $\begin{array}{l}\text { Amendment of By- } \\
\text { laws }\end{array}$ & Yes & Yes & No \\
\hline Liquidation Rights & Yes & Yes & No \\
\hline $\begin{array}{l}\text { Right to Bring } \\
\text { Derivative Suits }\end{array}$ & Yes & Yes & No \\
\hline $\begin{array}{l}\text { Protected by } \\
\text { Fiduciary Duties }\end{array}$ & Yes & Yes & No \\
\hline $\begin{array}{l}\text { Dual Class Stock } \\
\text { Permitted }\end{array}$ & Yes & Yes & No \\
\hline $\begin{array}{l}\text { Right to Enforce } \\
\text { PBC Purpose and } \\
\text { Mission }\end{array}$ & N/A & & \\
\hline
\end{tabular}

As the chart demonstrates, shareholders in Delaware PBCs retain the same degree of authority that they have in traditional corporations with respect to controlling corporate decisionmaking, directly and indirectly. Specifically, it is shareholders, and only shareholders, who elect the board of directors. Only shareholders vote on structural changes such as amendments to the charter and bylaws, mergers and reincorporations. Shareholders have the exclusive authority to convert a traditional corporation into a PBC and the right to convert back - in both cases by a simple majority vote as a result of the 2020 amendments. Only shareholders are protected by director and officer fiduciary duties, and only shareholders have the right to address wrongdoing by those directors and officers through litigation. ${ }^{47}$

Publicly-traded corporations face the additional consideration that only shareholders can impose capital market discipline on them. More specifically, shareholders trade the corporation's stock and therefore determine its price. Those trades are likely to be based, in large part, on the

\footnotetext{
47 The Delaware statute explicitly provides that directors do not have any duty to nonshareholders irrespective of the corporation's articulated public benefits. See D.G.C.L. $§ 365$ (b).
} 
PBCs ability to produce earnings and value. Critically, even if some shareholders value noneconomic aspects of the PBC's mission, prices are set by the marginal shareholder. ${ }^{48}$ This trading discipline will push management to adhere to a perspective which creates shareholder value. And the failure to adhere to create shareholder value, that is, economic value, will produce shareholder action in the form of proxy or other contests. It will also bring in the disciplining force of the M\&A market which will operate in the same manner as for a traditional corporation - a prospective bidder will set its offer price based on its ability to extract economic value. And finally, we do not discern a noticeable difference in incentive compensation in the publicly-traded PBCs and other corporations. ${ }^{49}$ This incentive structure will replicate management's focus on the stock price and economic performance.

As the chart indicates, although state statutes enable PBCs to identify an alternative social purpose, the statutes reserve to shareholders the right to enforce that purpose. Stakeholders lack any enforcement rights, even if a PBC explicitly identifies its mission as pursuing the interests of those stakeholders. Moreover, enforcement of the corporation's purpose even by shareholders is more difficult in the PBC than in a traditional corporation. In Delaware, the PBC statute limits the right to bring a lawsuit to enforce the directors duties under the statute to shareholders who own $2 \%$ or more of the corporation's stock. ${ }^{50}$ Other states authorize specific benefit enforcement proceedings but limit the power to initiative such proceedings to shareholders who own 5\% or more of the corporation's stock. ${ }^{51}$ In a publicly traded PBC, these larger shareholders are more likely to be institutional or other shareholders with fiduciary duties to their investors. These institutional shareholders have fiduciary duties to their own investors which will make it unlikely that they will bring a suit to reallocate the corporation's funds to its secondary non-profit purpose. To the extent they are available, enforcement proceedings only provide for potential injunctive relief; PBC statutes do not allow for the award of money damages in connection with a failure to adhere to the corporation's social purpose. ${ }^{52}$

Moreover, PBC statutes often provide broad discretion to directors to implement the PBC's mission as specified in the PBC charter. They expressly provide that disinterested failure to comply with PBC director duties does not constitute lack of good faith or breach of the duty of loyalty. They also expand the scope of the traditional business judgment rule. The Delaware statute, for example, articulates the necessary standard of conduct for PBC directors as "both

\footnotetext{
${ }^{48}$ See, e.g., Albert H. Choi \& Eric Talley, Appraising the "Merger Price" Appraisal Rule, 34 J. L. EcoON. \& ORG. 543 (2018) (observing that "The marginal shareholder effectively determines trading price, since her value reflects the lowest asking price for the stock...."). Notably, because a substantial percentage of the institutional money managed by firms that publicly articulate a commitment to social purpose is indexed, such investors are price takers whose views about social value do not influence their trading decisions. See, e.g., Jill E. Fisch, Assaf Hamdani \& Steven Davidoff Solomon, The New Titans of Wall Street: A Theoretical Framework for Passive Investors, 168 U. PA. L. REV. 17, 37 (2019) (explaining that "passive funds, by their very nature, must hold both the good and bad companies in their index.").

${ }^{49}$ For example, shortly after going public, Lemonade adopted an incentive award program in which it registered 3.75 million shares to be awarded to its officers and directors. See Lemonade, Inc. Form S-8 dated July 2, 2020, https://sec.report/Document/0001104659-20-080564/.

${ }^{50}$ D.G.C.L. $\$ 367$.

${ }^{51}$ See, e.g., CONN. GEN. STAT. ANN. § 33-1362(c) ("A benefit enforcement proceeding may be commenced or maintained only (1) directly by the benefit corporation, or (2) derivatively in accordance with the provisions of chapter 601 by (A) a person or group of persons that owns beneficially or of record not less than five per cent of the total number of shares of a class or series outstanding at the time of the act or omission complained of ...."). Similarly, the MBCA limits enforcement proceedings to 5\% shareholders. MBCA $\S 18.06(\mathrm{c})$.

52 See, e.g., MBCA $\S 18.06(\mathrm{c})$.
} 
informed and disinterested and not such that no person of ordinary, sound judgment would approve." 53

Finally, PBC statutes often offer little in the way of compliance monitoring. Most PBC statutes require that the PBC periodically report on the extent to which it had promoted its identified public benefits. ${ }^{54}$ This reporting may or may not require adherence to a third-party standard or outside certification. ${ }^{55}$ The Delaware PBC statute, for example, allows for auditing and enforcement of the PBC mission, but outside certification for compliance with a PBC's alternative purpose is not required unless stockholders elect to require it. ${ }^{56}$ And in Delaware even this disclosure mandate is limited by the fact that the mission is only enforceable by shareholders. ${ }^{57}$ Those commentators who have studied compliance rates have consistently reported low levels of compliance. For example, an early study by J. Haskel Murray reported compliance with state reporting requirements at a rate of 8-10\%. ${ }^{58}$ Eric Franklin Amarante reported that only one of 697 Nevada benefit corporations posted the required benefit report on its website. ${ }^{59}$ More recent work has reported that, although compliance rates vary, most are still well below $20 \% .{ }^{60}$

Ultimately, an analysis of the PBC finds that, apart from its designated social purpose and the obligation to consider or balance stakeholder interests, it is structured in the same manner as a traditional corporation. Meanwhile, existing law imposes few checks on PBC behavior designed to ensure enforcement of the PBC's social purpose, and vehicles for shareholder enforcement appear weak at best. If publicly-traded PBCs are to operate differently from traditional corporations, that result is unlikely to be a product of the PBC's legal structure. Moreover, to provide recourse if a $\mathrm{PBC}$ strayed from its designated objectives, even a more vigorous enforcement mechanism would require a more clearly-defined social purpose. We take up this point in the next section.

\section{Examining Purpose in PBCs}

Chart A highlights that the key structural mechanism differentiating PBCs from traditional corporations is their statement of purpose. As noted above, PBC statutes generally allow or require a PBC to identify a secondary social purpose, but the statutes offer limited guidance as to what that statement of purpose is supposed to look like. Most PBC statutes do not provide affirmative guidance as to what constitutes a permissible corporate purpose. The Delaware statute, for example, requires a PBC to identify one or more specific public benefits, which are defined as "a positive effect (or reduction of negative effects) on 1 or more categories of persons, entities, communities or interests (other than stockholders in their capacities as stockholders) including, but not limited to, effects of an artistic, charitable, cultural, economic, educational, environmental,

\footnotetext{
${ }^{53}$ D.G.C.L. $§ 365$.

${ }^{54}$ See generally Maxime Verheyden, Public Reporting by Benefit Corporations: Importance, Compliance, and Recommendations, 14 HASTINGS BUS. L.J. 37 (2018) (describing legal requirements for benefit corporation reporting and analyzing reporting practices by benefit corporations in four states).

${ }^{55}$ See id.

56 D.G.C.L. $\S 366$.

${ }^{57} \mathrm{Id}$. at $\S 367$.

${ }^{58}$ J. Haskell Murray, An Early Report on Benefit Reports, 118 W. VA L. REV. 25, 34-35 (2015).

59 Eric Franklin Amarante, Nudging Entrepreneurs into Noncompliance: Why Does Nevada Have so Many Benefit Corporations? [Blog Post] (September 23, 2016), available at https://ssrn.com/abstract=2897684.

${ }^{60}$ Verheyden, supra note 54.
} 
literary, medical, religious, scientific or technological nature."61 Statutes are largely agnostic between corporations that pursue a specific public benefit objective such as reducing climate change or promoting workplace safety and those that seek to operate within the framework espoused by purpose advocates such as limiting externalities, providing a net benefit to society or managing the corporation in the interests of all its stakeholders. ${ }^{62}$ It is also unclear whether the PBC statute contemplates social purpose as a matter for individual corporate choice or whether social purpose requires operations that pursue an overall benefit to society.

That statutes do not mandate more specific guidelines for a PBC's social purpose is neither surprising nor inherently problematic. If the $\mathrm{PBC}$ form encourages a range of businesses to operate in a more socially responsible manner, after all, what is wrong with letting a thousand flowers bloom? But it is critical to recognize the resulting shortcomings in what we can expect in terms of commitment. A PBC does not commit, through its choice of business form, to minimize negative externalities from its operations. It does not pledge to operate in a manner that furthers the interests of all those affected by its business. It need not promote a cleaner environment, workplace diversity or responsible supply chain practices.

Instead, PBCs themselves identify the principles by which they are to be evaluated, through their articulation of social purpose. We turn then to an evaluation of the manner in which some of the largest PBCs do so. To explore this question, we obtained the charters of 14 Delawareincorporated PBCs. Exhibit A sets forth a list of these companies along with their PBC specified purpose. These charters include the 4 publicly-traded PBCs (i.e., Laureate Education, Lemonade, Veeva, and Vital Farms). The remaining 10 are the ten largest PBCs receiving outside venture capital investment as documented in a separate article by one of the co-authors. We include these 10 companies because they are the ones who are most likely to go public in the coming years and have venture capital funds with fiduciary obligations to their investors as major stockholders. As noted above, the Delaware PBC statute requires that PBCs identify at least one specific public benefit in their charter.

Although our sample is neither extensive nor necessarily representative of the universe of PBCs, we find that the purpose statements of the PBCs in our sample are largely vague and aspirational. They do not provide shareholders and other interested stakeholders with meaningful guidance on their intended operations or priorities. Nor do they enable shareholders to monitor effectively whether the PBC is complying with its stated goals.

Recently-public Lemonade, Inc. provides a good example. Its stated purpose is to "harness technology and social impact to be the world's most loved insurance company."63 While this

\footnotetext{
${ }^{61}$ D.G.C.L. $\S 362(\mathrm{~b})$.

${ }^{62}$ Lyman Johnson characterizes these as two types of PBCs - a specific benefit corporation and a general benefit corporation and argues that the latter is required to pursue a net positive benefit on society. Accordingly, a specific benefit corporation need only pursue its identified public benefit and is not required to prioritize all the stakeholders identified in materials such as the Business Roundtable statement. See Johnson, supra note 15. Further, as some commentators have noted, the language of some statutes is ambiguous on the relationship between specific and general purpose. For example, a number of statutes require that the corporation's directors "consider" the interest of a broad range of stakeholders, but the only obligations that are arguably enforceable relate to the corporation's designated specific purpose.

${ }^{63}$ Wallace Witowski, Lemonade IPO: 5 things to know about the online insurer, MARKETWATCH, Jul. 2, 2020, available at https://www.marketwatch.com/story/lemonade-ipo-5-things-to-know-about-the-online-insurer-2020-07-01 (last accessed, Sept. $15,2020)$.
} 
purpose appears to comply with the Delaware statutory requirement of a positive effect "of ... a technological nature" the statement does not indicate the target audience whose love is sought - is it customers, employees, shareholders or someone else? Does Lemonade seek to be loved by its own customers or by customers of its competitors? Is it to be loved for its competence in the insurance industry or for its collateral good works such as its charitable donations policy?

Veeva which converted from a for-profit corporation to a $\mathrm{PBC}$ with great fanfare, has as its corporate purpose:

The Corporation shall be a public benefit corporation, as contemplated by subchapter XV of the DGCL, and is to be managed in a manner that balances our stockholders' pecuniary (financial) interests, the best interests of those materially affected by the corporation's conduct (including customers, employees, partners, and the communities in which we operate), and the public benefits identified in this certificate of incorporation. We believe this corporate structure reflects our guiding principle, "do the right thing." The specific public benefits to be promoted by the Corporation are to provide products and services that are intended to help make the industries we serve more productive, and to create highquality employment opportunities in the communities in which we operate. ${ }^{64}$

We agree that corporations and people should "do the right thing", but struggle how this can be an implementable principle that is legal enforceable. Similarly, the specific benefit Veeva puts forth - making industries more productive and creating high quality employment opportunities is unquantifable and immeasurable. The effect of this purpose therefore is uncertain, particularly since Veeva has dual-class stock and is controlled by its CEO and co-founder.

Other purpose statements are similar. Vital Farms' secondary purpose is to inter-alia "bring[] joy to our customers through products and services." 65 In the private sphere, Global Uprising PBC, sets forth as its purpose as:

using its business to inspire social and environmental change that results in the improvement of the human condition, increased social consciousness and the amelioration of poverty. ${ }^{66}$

Ripple Foods, another private company that has taken substantial venture capital investment, has a similarly aspirational purpose. Its purpose statement provides that "the Corporation shall have a public benefit purpose of producing a material positive impact on society and the environment, taken as a whole, assessed against a third-party standard." ${ }^{\circ 7}$ Arguably there are two advantages to this statement. First, Ripple has seemingly committed to a net positive impact, limiting its ability to focus on specific social goals at the potential expense of other interests. Second, Ripple cites it commitment to having its actions evaluated against a third party standard. On the other hand, what does it mean to produce a material positive impact taken as a

\footnotetext{
${ }^{64}$ Veeva Restated Certificate of Incorporation, dated Feb. 1, 2021, at pp.1-2, available at https://www.sec.gov/Archives/edgar/data/1393052/000162828021001246/veevex31feb2021.htm.

${ }^{65}$ Exhibit A.

${ }^{66} \mathrm{Id}$.

${ }^{67} \mathrm{Id}$.
} 
whole? May Ripple use less environmentally friendly packaging if it promotes customer safety? What are Ripple's obligations to alert customers as to the nutritional differences between its milk alternative and the comparable dairy products? And again, how do shareholders and others assess compliance with Ripple's purpose, given the broad discretion that it provides?

Ultimately, while we do not review all PBC corporate charters, the charters of the most economically significant PBCs and those that are publicly-traded put forth purpose statements so vague and aspirational that is it hard to think of them as providing any content or ability to monitor them in the public markets. Indeed, in our sample, the only statement that appears to be capable of objective measurement is MPower, which has adopted as its purpose: "[t]he specific public benefit purpose of the corporation is: Lending to Students of Low-Income Backgrounds." 68 This is in line with the business of the company which is "[w]e're a social benefit corporation founded by international students for international students, and we're on a mission to make socioeconomic mobility borderless." 69

Mindful of the argument that people should be judged by their actions and not by their words, we further evaluate PBCs by their operational decisions. Here we note the limitations of the PBC form in providing a standard by which to evaluate that conduct. For example, charitable donations reflect a substantial component of Lemonade's public identify. Lemonade touts the program by which it allows customers to designate a charitable cause to which the company will donate residual premiums. The overall amount of Lemonade's donations through this program is limited, however, in comparison to charitable giving by traditional insurers. ${ }^{70}$ In fiscal 2019 Lemonade donated $\$ 631$ thousand total on revenue of $\$ 63$ million, or approximately 1 percent of Lemonade's total revenue. ${ }^{71}$ Lemonade's donations increased to over a million dollars in fiscal 2020, an amount larger than its donations for the previous three years combined. ${ }^{72}$ Significantly, however, Lemonade has yet to earn a profit. Although shareholders may tolerate charitable donations that are small in overall dollar amount, for now, it is unclear how long they will continue to love a company that cannot navigate a path to profitability. ${ }^{73}$

Another prominent PBC is Kickstarter. The Company states that its secondary "mission is to help bring creative projects to life; Kickstarter's operations will reflect its values; Kickstarter supports a more creative and equitable world; Kickstarter is committed to the arts; and Kickstarter

\footnotetext{
${ }^{68} I d$.

${ }^{69}$ MPower Financing Website, available at https://www.mpowerfinancing.com/ (last accessed Sept. 15, 2020).

${ }^{70}$ Lemonade Website, The Lemonade Giveback, available at https:/www.lemonade.com/giveback ("Lemonade takes a flat fee and treats the rest of the money as yours, not ours. We use it to pay claims, and give what's left to charities you choose, so we never fight over the same coin.") (last accessed Sept. 15, 2020).

${ }^{71}$ Lemonade had no profits, but these figures are comparable to publicly traded corporations. According to one recent survey, the 300 largest companies on the Fortune 500 list provided about $1 \%$ of pretax profits to charity. The highest was Gilead at $2.9 \%$ (\$338 million). See Ben Paynter, Big companies donate a smaller percentage of their income than regular people, FastCompany, Sept. 13, 2018, available at https://www.fastcompany.com/90233934/big-companies-donate-a-small-percentage-of-their-incomethan-regular-people (last accessed Sept. 15, 2020).

${ }_{72}$ Lemonade, PBC, Lemonade's 2020 Giveback Hits New High, Backing 34 Nonprofits Chosen By Customers, dated at Aug. 6 , 2020, available at https://www.businesswire.com/news/home/20200806005610/en/Lemonade\%E2\%80\%99s-2020-GivebackHits-New-High-Backing-34-Nonprofits-Chosen-By-Customers

${ }^{73}$ See, e.g., Kristin Broughton, Lemonade CFO Promotes Do-Good Status, Path to Profitability to New Investors, WaLl. ST. J., Aug. 30, 3030, available at https:/www.wsj.com/articles/lemonade-cfo-promotes-do-good-status-path-to-profitability-to-newinvestors-11598792401 (observing that investors are demanding Lemonade provide information on its strategy for achieving profitability).
} 
is committed to fighting inequality." In this regard the Company's latest report promotes a host of social involvement including an environmental impact statement. ${ }^{74}$ The company also donates $5 \%$ of its profits to charity for the arts and inequality.

However, while Kickstarter shows evidence of living up to its value, it was engaged in conflict with its own workers and allegedly terminated 2 of them for union organizing efforts. ${ }^{75}$ The employees of Kickstarter ultimately voted to unionize by a margin of 46 to 37 in an election held by the National Labor Relations Board. Kickstarter opposed the unionization effort and its CEO resigned in the midst of the dispute. In the wake of the coronavirus epidemic the company has stated it is laying off up to $45 \%$ of its staff. To the extent that a PBC commits to operate so as to produce a net positive impact on society, how does one weigh Kickstarter's social involvement against the potentially negative impact it has had on its employees?

Our point here is not to make a normative statement on Kickstarter's or Lemonade's social welfare efforts. Nor is to state that all PBCs should be perfect in some normative social purpose manner. But our point is that in the absence of a definable and recordable purpose for PBCs, these entities tend to resort to soft value statements, assertions which can be trumped by shareholder wishes and profit-minded actions. Moreover, the implementation of these value statements is hard to assess and often merely anecdotal. Nor do these value statements allow assessment of the company's total conduct. These issues are only likely to be exacerbated in the public markets where the structure of investment, compensation and shareholder rights will push PBCs to replicate the regular corporation in ultimate operations and objections. ${ }^{76}$

\section{PBCs and Accountable Purpose}

Our review indicates that the legal structure of PBCs, like that of traditional corporations, is shareholder-centric. Similarly, although PBCs are theoretically constrained by the requirement that they articulate a social purpose, we find that the largest PBCs frequently articulate a social purpose that is vague and unmeasurable. We are thus skeptical that many of the economic and other benefits that some commentators have argued can be achieved simply by encouraging or compelling traditional publicly-traded corporations to embrace the PBC form. Similarly we question the extent to which encouraging or requiring that companies convert to PBCs will produce any meaningful change in their conduct.

\section{A. The PBC Commitment Problem - Two Case Studies}

We do not think the preceding analysis precludes publicly-traded companies from usingthe $\mathrm{PBC}$ form effectively. Rather we believe that the PBC has the potential to offer a meaningful opportunity for business participants to implement a broader societal mission over and above a

\footnotetext{
${ }^{74}$ KiCKSTARTER PBC 2018 Benefit StATEMENT, at 2, available at https://d3mlfyygrfdi2i.cloudfront.net/ugm6tgt9FINAL PBC Report 20190902.pdf (last accessed Sept. 15, 2020).

${ }^{75}$ Jack Kelly, Employees Cast a Historic Vote to Unionize at Kickstarter, ForBES, Feb. 19, 2020, available at https://www.forbes.com/sites/jackkelly/2020/02/19/employees-cast-a-historic-vote-to-unionize-at-kickstarter/\#7025745d4822

${ }^{76}$ We note here again, the significance of ownership structure. By way of contrast, King Arthur Flour, a benefit corporation, has one of the most detailed reports on its objectives and accomplishments. See King Arthur Flour, Benefit Corporation Annual Report 2019, https://www.kingarthurbaking.com/sites/default/files/2020-12/2019-BCorpReport.pdf . KAF is, however, 100\% employee-owned. Id. at 4.
} 
for-profit corporation. The potential value of a PBC includes the ability of founders and stockholders to precommit to a particular social mission and to formalize their agreement on the objectives and priorities of that mission. However, we also identify the risk that, for publiclytraded PBCs, such broader benefits may be trumped by stockholders expressing ordinary concerns about economic value. The experience of two well-known corporations illustrates this point.

The first is Etsy. Etsy went public in 2015 as a certified B-Corp. Its Registration Statement emphasized its status as a B-corp, stating "[f]undamentally, we believe that companies can and should use the power of business to create social good, which is reflected in our status as a Certified B Corporation. Our commitment to using business as a force of good manifests itself in the way we run our business." 77

However, as soon as Etsy went public, it faced pressure from market forces to change the way it operated. As the N.Y. Times reported in 2017:

By late last year, expenses were growing fast. And even as the company reported $\$ 88$ million in revenues during the third quarter, it posted a net loss of $\$ 2.5$ million. After a few quarters of tepid results, investors grew impatient and a classic clash of corporate governance came spilling into view - how would a company like Etsy balance the shortterm demands of its shareholders with its high-minded long-term mission? ${ }^{78}$

The result was a return to shareholder primacy. The board, under shareholder pressure, terminated the CEO and replaced him with a new CEO from Skype. The company laid off $8 \%$ of its staff in connection with the CEO replacement. An activist shareholder, Black-and-White Capital, took a position in the company and a board seat. And private equity firms then stepped in to provide capital but on terms that demanded a greater focus on economics. The company subsequently terminated its B-Corp certification. We offer the events of Etsy as a cautionary tale, but also as real evidence that the current PBC form can readily be usurped by market forces.

The case of Ben and Jerry's is also illuminating. Although Ben \& Jerry's, a publicly-traded one organized under the laws of Vermont, was not a PBC, it espoused a broad social purpose similar to that of the PBC. Among other things, Ben \& Jerry's committed to donating $7.5 \%$ of its pretax profits to charity through the Ben \& Jerry's Foundation. Ben \& Jerry's was eventually bought by Unilever in 2000. Both Ben and Jerry have individually attributed the sale to the requirements of the board's fiduciary duties to act in the interest of shareholders. ${ }^{79}$ There is some dispute over this matter, but regardless the company was subject to the market for corporate control. Lacking majority control, Ben and Jerry could not block a takeover. ${ }^{80}$

\footnotetext{
${ }^{77}$ Etsy, Inc. Registration Statement on Form S-1, at p. 92.

${ }^{78}$ Gelles, supra note 10.

79 Anthony Page \& Robert A. Katz, The Truth About Ben \& Jerry's, Stanford Social InNOvation ReVIEW (Fall 2012).

${ }^{80}$ Notably the increasing tendency of at least some founders to use dual class stock to retain voting control after taking a company public offers a potential way to insulate a PBC's social purpose from some of this vulnerability.
} 
Today, Ben \& Jerry's is still owned by Unilever and is organized as a private PBC. Ben \& Jerry's has maintained its commitment to engaging in social causes. ${ }^{81}$ However, Ben \& Jerry's social positions are supported by annual allocations from Unilever. In 2015, Unilever only donated $\$ 2.8$ million to the Ben \& Jerry Foundation - about half a percent of the company's revenue. ${ }^{82}$ It is unclear if the company has maintained its pre-acquisition charitable mission rather than become part of a $\$ 100$ billion plus conglomerate.

These two examples highlight the issues faced by publicly-traded PBCs. The absence of a clearly-defined social purpose and a mechanism for enforcing that purpose exacerbate the risk that social purpose will be abandoned in favor of profit or expediency. To the extent that the PBC form is about marshalling momentum and energy behind the corporation because shareholders and stakeholders alike believe it is better than the traditional corporation, then the structural limitations that we have identified are not problematic. ${ }^{83}$ Similarly, the PBC designation may find support in the marketplace for the corporation's social mission, allowing the corporation to do well by doing good.

The problem arises in cases in which social purpose and economic value are not aligned. In addition, the PBC is vulnerable to purpose drift, in which its decisionmakers - whether officers, director or controlling shareholders - identify alternative social objectives or priorities at the potential expenses of other stakeholders who have committed to relationships with the corporation premised on priorities that have fallen out of favor. The PBC form may also serve as a vehicle for corporate greenwashing - purporting to pursue a social mission while failing to do so, for the purpose of obtaining the social capital and goodwill associated with that mission, Most problematically, the current requirements of the PBC do little to ensure that the $\mathrm{PBC}$ is truly operated in an effort to pursue social benefit.

These concerns are exacerbated by the recent amendments to the Delaware statute and the MBCA which facilitate the conversion from a PBC to a traditional corporation. A majority of shareholders can abandon social purpose to the detriment of both the minority shareholders and other stakeholders that have entered into relationships with the corporation based on a commitment that proves illusory. Given the outcome of the Etsy and Ben \& Jerry's stories, this possibility should not be ignored.

\section{B. A Concrete Statement of Purpose}

In some respects, one could argue that the response to the issues we raise is to do nothing. After all, it is early days for the PBC, especially the publicly-traded PBC. Should publicly-traded

\footnotetext{
${ }^{81}$ Ben and Jerry's mission is now “a three-part mission that aims to create linked prosperity for everyone that's connected to our business: suppliers, employees, farmers, franchisees, customers, and neighbors alike.” Ben \& Jerry's Website, Our Values, available at https://www.benjerry.com/values (last accessed Sept. 15, 2020).

82 Somewhat surprisingly, neither the Ben \& Jerry's page on the Unilever website or the page for the Ben \& Jerry's Foundation appear to contain any recent financial information. See Ben \& Jerry's, https://www.unileverusa.com/brands/food-and-drink/benand-jerrys.html; and Ben \& Jerry's Foundation, https://benandjerrysfoundation.org/about-us.html.

${ }^{83}$ Indeed, consistency and monitoring facilitate a PBC's ability to capitalize on its social objectives in the market. See, e.g., J. Haskell Murray, Social Enterprise Innovation: Delaware's Public Benefit Corporation Law, 4 HARV. BuS. L. REv 345,357 (2014) (stressing the importance of consistency, monitoring and enforcement to maintain a useful brand).
} 
companies adopt the PBC form more broadly, that movement will likely enhance the form's stature and create network effects that will further facilitate its use. ${ }^{84}$

Nonetheless, we believe that if the PBC is to be sustainable in the public markets it must evolve further. Our suggestion in this regard is twofold. First, we suggest that, as corporations increasingly use the PBC form, they should set forth a more concrete, measurable social purpose in their charter. This would allow the board and shareholders to set expectations about the exact social mission of the PBC up front. And it would allow non-shareholder stakeholders, including customers, employees and regulators, to evaluate the performance on the company against its social purpose claims. This type of specifity is particularl relevant when the public company has dual class stock in which a vague purpose can provide for rent-seeking by the controlling shareholders.

What do we mean by a clear social purpose? We suggest several considerations. First a PBC should identify a discrete primary purpose, which can be unidirectional, such as minimizing pollution or multifaceted, such as furthering the interests of an identified set of stakeholders. Where the identified purpose encompasses multiple objectives, it should designate those goals that the corporation will prioritize, recognizing the potential need to trade-off between competing objectives such as low prices and responsible supply chain practices. ${ }^{85} \mathrm{We}$ further suggest that the social purpose be articulated in terms that can be measured or benchmarked against publiclyavailable standards. Reducing workplace accidents, maintaining a net-zero carbon footprint, increasing the number of loans to minority-owned businesses are examples.

To be clear, we are not advocating narrowing what qualifies as a public purpose. The PBC is a new business form, and there are multiple paths to improving society. We expect that some PBCs will articulate a very specific purpose, such as Patagonia's commitment to environmental responsibility, while others will seek to minimize externalities with respect to a range of stakeholders. Our proposal is merely that both shareholders and other stakeholders have the tools to differentiate among these purposes and to hold a particular PBC accountable to the goals that it sets for itself. Toward that end, we advocate greater attention to meaningful mechanisms for imposing such accountability, mechanisms that we discuss in the next section.

\section{Accountability Mechanisms}

A measurable and discrete social purpose only gets us halfway to enabling meaningful commitment by PBCs. So long as the charter is sufficiently concrete, it should be clear that a corporation has departed from its public purpose. The other piece of the equation is a mechanism for addressing that departure.

We acknowledge that this is a complex issue worthy of its own article, but several approaches are possible in this regard. One possibility is to revise PBC statutes to enable

\footnotetext{
${ }^{84}$ We are not the first to make this point. See Dana Brakman Reiser, Theorizing Forms for Social Enterprise, 62 Emory L.J. 681 (2013) (examining "the broader theoretical question of what [social enterprise] specialized forms would have to provide in order for them to help social enterprise to realize its claimed potential.")

${ }^{85}$ For further discussion of this approach, see Roxanne Thorelli, Note: Providing Clarity for Standard of Conduct for Directors Within Benefit Corporations: Requiring Priority of a Specific Public Benefit, 101 MinN. L. REV. 1749, 1769-1770 (2017).
} 
shareholders to impose meaningful accountability. Because of the PBC's shareholder-centric structure, a PBC is unlikely to be vulnerable to either abandonment of its purpose or drift unless a majority of shareholders are complicit. At a minimum, minority shareholder litigation in the form of a derivative suit could provide a meaningful mechanism for redress.

EExisting PBC statutes constrain shareholder litigation even beyond the protections provided to corporate decisionmaking in traditional corporations, thereby minimizing the potential for shareholders to hold officers and directors accountable for adhering to the PBC's mandate. ${ }^{86}$ The Delaware PBC statute, for example, does not permit shareholder litigation unless initiated by at least $2 \%$ of the outstanding shares or, in the case of a publicly-traded PBC, $\$ 2$ million worth of stock. ${ }^{87}$ Other states impose similar requirements. ${ }^{88}$ Some statutes provide a specialized enforcement mechanism, a "benefit enforcement proceeding," as an alternative to traditional fiduciary duty litigation, but the statutory threshold to initiate such a proceeding is typically as high or higher. ${ }^{89}$ The Delaware statute also expands the scope of the business judgment rule ${ }^{90}$ and the definition of good faith ${ }^{91}$ to insulate director decisions further. We question whether those constraints are appropriate or if they are likely to result in suboptimal levels of accountability. ${ }^{92}$ The institutionalization of the securities markets means that a relatively small percentage of publiccompany stock is owned by retail shareholders, and institutional investors face a variety of structural and reputational constraints that make their leadership in policing PBCs unlikely. ${ }^{93}$ Given the lack of availability of money damages ${ }^{94}$ (a limitation we would retain), the potential for frivolous or lawyer-driven litigation in this area seems unlikely.

We do not want to overstate the value of shareholder litigation however. In particular, we note that in other arenas shareholder litigation has resulted in significant costs and little benefit. In addition, facilitating shareholder litigation still leaves enforcement in the hands of shareholders, an approach that, for the reasons discussed above, is problematic in that shareholders arguably have the control to maintain the PBC's commitment to its social purpose through their voting

\footnotetext{
${ }^{86}$ See notes 50 through 53 supra and accompanying test.

878 Del. C. $\$ 367$.

${ }^{88}$ See Joan MacLeod Heminway, Corporate Purpose and Litigation Risk in Publicly Held U.S. Benefit Corporations, 40 Seattle U. L. ReV. 611, 638-39 (2017) ((citing thresholds in Colorado and Tennessee),

${ }^{89}$ Id. at 631 (reporting minimum ownership thresholds of 2 or $5 \%$ ).

90 See 8 Del. C. $\$ 265$ (b) (providing that a director's decision satisfies his or her fiduciary duties “if such director's decision is both informed and disinterested and not such that no person of ordinary, sound judgment would approve").

${ }^{91}$ See 8 Del. C. $\$ 265$ (c) (providing that "in the absence of a conflict of interest, no failure to satisfy [requirement to balance stakeholder interests shall] "constitute an act or omission not in good faith").

${ }^{92}$ See See Heminway, supra note 88 at 638 (arguing that "by affording a right of action only to derivative plaintiffs having a requisite percentage or dollar value of shareholdings, benefit corporation laws may decrease the prospect of fiduciary duty enforcement litigation").

${ }^{93}$ See, e.g., Sean J. Griffith \& Dorothy S. Lund, A Mission Statement for Mutual Funds in Shareholder Litigation, 87 U. CHI. L. REV. ONLINE 1149 (2020) (detailing the limited involvement by mutual funds in shareholder litigation); $c f$. Jill E. Fisch, The Destructive Ambiguity of Federal Proxy Access, 61 EMORY L.J. 435, 462-64 (2012) (observing that the 3\% minimum ownership requirements of the SEC's proxy access rule was sufficiently high as to make its use unlikely).

${ }^{94}$ See Heminway, supra note 88 at 631 (describing statutory provisions banning money damage awards for failure to pursue designated public benefits); William H. Clark, Jr. \& Elizabeth K. Babson, How Benefit Corporations Are Redefining the Purpose of Business Corporations, 38 Wm. Mitchell L. Rev. 817, 848-49 (2012) (stating that California's benefit corporation statute "specifically excludes director, officer, and corporate liability for monetary damages").
} 
power as well as the incentive to abandon that commitment in favor of economic value. ${ }^{95}$ An alternative is to increase the role of other stakeholders. Brett McDonnell has suggested that stakeholder power is the tool to enhancing a firm's ability to commit to social enterprise. ${ }^{96}$ Such power could be created through allocating voting rights to some non-shareholder stakeholders or by providing for stakeholder representation on the board of directors. Elizabeth Warren's Accountable Capitalism Act ${ }^{97}$ and Germany's codetermination regime ${ }^{98}$ offer examples of ways in which to implement greater stakeholder power.

A third option is public enforcement. The commitments of non-profit corporations are enforced, in part by State Attorneys General, although in practice such enforcement actions are rare. As Evelyn Brody has observed, "as a practical matter, few state attorneys general have the funding and inclination to engage in aggressive charity enforcement." 99 If a PBC's disclosure requirements are incorporated into federal securities reporting, the Securities \& Exchange Commission could also enforce those requirements. ${ }^{100}$ Still another approach would be to create a specialized regulator to impose accountability and enforce stakeholder interests. ${ }^{101}$

Other commentators have explored these proposals in further detail than space constraints permit here. We merely note the existence of a range of options that, coupled with a concrete statement of purpose, have the potential to enhance the PBC's commitment to its mission.

\section{Conversion}

In addition to a PBC's general operations, there is also the issue of conversion. A PBC's shareholders retain the power to convert it back to a traditional corporation, and this conversion has become easier under the amended Delaware statute and analogous amendments to the MPBCA. Although we do not yet see examples of such conversions and indeed, they are unlikely in the current political climate, the prospect of such conversion raises the potential of undermining a PBC's commitment to its social purpose. We note that this risk is particularly great in situations in which a PBC's insulating ownership structure - dual class or employee ownership - changes and subjects the PBC to increased market discipline.

One potential question raised by such a conversion is the role of the board. Because conversion requires both board and shareholder approval, the board's decision to convert is subject

\footnotetext{
${ }^{95}$ See, e.g., Thomas J. White, Benefit Corporations: Increased Oversight through Creation of the Benefit Corporation Commission, 41 J. LEGIS. 329, 347 (2015) (questioning whether shareholders will protect stakeholders interests when those interests conflict with their own).

${ }^{96}$ Brett H. McDonnell, From Duty and Disclosure to Power and Participation in Social Enterprise, 70 Ala. L. Rev. 77 (2018).

97 The Accountable Capitalism Act, S. 3348, 115th Cong. (2018).

${ }^{98}$ See, e.g., Jens Dammann, \& Horst G. M. Eidenmueller, Codetermination: A Poor Fit for U.S. Corporations (April 1, 2020), European Corporate Governance Institute - Law Working Paper No. 509/2020, available at https://ssrn.com/abstract=3565955 (explaining Germany's system of codetermination and arguing that it is a poor fit for US corporations).

${ }^{99}$ Evelyn Brody, Whose Public? Parochialism and Paternalism in State Charity Law Enforcement, 79 IND. L.J. 937,939 (2004).

${ }^{100}$ See, e.g., Brent J. Horton, Rising to Their Full Potential: How a Uniform Disclosure Regime Will Empower Benefit Corporations, 9 HARV. Bus. L. REV. 101, 104 (2019) (proposing a uniform disclosure regime for PBCs enforceable by the SEC through cease-and-desist proceedings). To the extent state statutes impose reporting requirements, private securities fraud litigation could also supplement public enforcement for fraudulent or misleading disclosures. See See Heminway, supra note 88, at 641-43 (evaluating potential for federal securities fraud litigation but noting the difficulty of establishing loss causation).

${ }^{101}$ See, e.g., White, supra note 95, at 346-52 (2015) (advocating for the creation of a Benefit Corporation Commission which would act as a more reliable guardian of stakeholder interests).
} 
to fiduciary principles. Because PBC statutes define the PBC's best interests to incorporate its designated social purpose, a board presumably need not approve an opportunistic conversion that sacrifices the interests of minority shareholders, stakeholders or the public at large. Moreover, the basis on which a board evaluated the corporation's best interests would be subject to judicial review, in which legal standards such as Unocal and Revlon may also be implicated. We acknowledge that these issues will require more thought and study as the role of the PBC becomes better understood.

\section{Conclusion}

The PBC is a new, highly-touted form, and the market is just beginning to see the emergence of the publicly-traded PBC. As more companies in the public market face public pressure to utilize the $\mathrm{PBC}$ corporate form, it will be important to keep fundamental principles of the $\mathrm{PBC}$ in mind, namely preserving its social purpose. As we have outlined in this chapter, preserving that social purpose may be difficult for publicly-traded PBCs. The fundamental structure of PBCs preserves extensive shareholder control while subjecting the PBC to the forces of the capital markets, and these forces are likely to push PBCs into similar profit-oriented decisions as those made by traditional corporations. In addition, the vague and unenforceable purposes put forth by PBCs are unlikely to prove effective in promoting accountability and limiting purpose drift.

We propose that publicly-traded PBCs evolve and adopt a more specific and definite corporate purpose as a partial solution to these concerns. A concrete social purpose would provide a basis for stakeholders to evaluate the PBC's mission and to determine their compatibility with its objectives on an ex ante basis. We further highlight the need for functional mechanisms to hold the PBC's board accountable to that purpose. While a finding that a board failed to adhere to its social purpose would presumably require a high standard, we believe that enforcement of the PBC's social purpose is necessary to achieve a meaningful difference between the legal structure and mission of a PBC and a traditional corporation.

Exhibit A

Significant PBCs and Their Legal Social Purpose

$\underline{\text { Private Companies }^{102}}$

\begin{tabular}{|l|l|}
\hline $\begin{array}{l}\text { Company } \\
\text { Name }\end{array}$ & Statement \\
\hline
\end{tabular}

102 Top-ten PBC recipients of venture capital funding per Dorff, et al., supra note 25. 


\begin{tabular}{|c|c|}
\hline $\begin{array}{l}\text { AltSchool, } \\
\text { PBC }\end{array}$ & $\begin{array}{l}\text { (Name Change Amendment Filed 10/08/2014) } \\
\text { Article III: Purpose } \\
\text { The Corporation is a public benefit corporation organized under the General } \\
\text { Corporation Law and the Corporation has elected to be subject to Section } 361 \text { of the } \\
\text { General Corporate Law. The Corporation shall have a public benefit purpose of } \\
\text { creating a material positive impact on society and to operate in a responsible and } \\
\text { sustainable manner, as required under Section } 363 \text { of the General Corporate Law. } \\
\text { This impact shall be assessed by evaluating the business and operations of the } \\
\text { Corporation as a whole. The Corporation also has a specific public benefit purpose to } \\
\text { promote innovation in education and improved access to quality schooling. }\end{array}$ \\
\hline $\begin{array}{l}\text { MPOWER } \\
\text { Financing }\end{array}$ & $\begin{array}{l}\text { (Filed 04/01/2014) } \\
\text { Article III: The specific public benefit purpose of the corporation is to: Lending to } \\
\text { Students of Low-Income Backgrounds }\end{array}$ \\
\hline Qwil & $\begin{array}{l}\text { (Filed 07/08/2019) } \\
\text { Article III: The purpose of the Corporation is to engage in any lawful act or activity } \\
\text { for which a corporation may be organized under the General Corporation Law of the } \\
\text { State of Delaware, as the same exists or as may hereafter be amended from time to } \\
\text { time. The specific public benefit purpose of the Corporation is to create a material } \\
\text { positive impact on society, taken as a whole, as assessed against a third-party } \\
\text { standard, from the business and operations of this Corporation. }\end{array}$ \\
\hline $\begin{array}{l}\text { Ripple Foods, } \\
\text { PBC }\end{array}$ & $\begin{array}{l}\text { (Filed 12/15/2014) } \\
\text { Article III: Purpose: The Corporation is a public benefit corporation organized under } \\
\text { the General Corporation Law and the Corporation has elected to be subject to Section } \\
361 \text { of the General Corporation Law. The Corporation shall have a public benefit } \\
\text { purpose of producing a material positive impact on society and the environment, taken } \\
\text { as a whole, assessed against a third-party standard, from the business and operations } \\
\text { of a public benefit corporation, as required under Section } 362 \text { of the General } \\
\text { Corporation Law. This impact shall be assessed by evaluating the business and } \\
\text { operations of the Corporation as a whole. }\end{array}$ \\
\hline $\begin{array}{l}\text { Allbirds, Inc. } \\
\text { (Bozz) }\end{array}$ & $\begin{array}{l}\text { (Filed 07/19/2016) } \\
\text { THIRD: The nature of the business or purposes to be conducted or promoted is to } \\
\text { engage in any lawful act or activity for which corporations may be organized under } \\
\text { the General Corporation Law. The Corporation shall be a public benefit corporation as } \\
\text { contemplated by subchapter XV of the General Corporation Law, or any successor } \\
\text { provisions, that it is intended to operate in a responsible and sustainable manner and } \\
\text { to produce a public benefit or benefit, and is to be managed in a manner that balances } \\
\text { the stockholders pecuniary interests, the best interests of those materially affected by } \\
\text { the corporation's conduct and the public benefit or benefits identified in this } \\
\text { certificate of incorporation. If the General Corporation Law is amended to alter or } \\
\text { further define the management and operation of public benefit corporations, then the } \\
\text { Corporation shall be managed and operated in accordance with the General } \\
\text { Corporation Law as so amended. In addition, the Corporation will promote the } \\
\text { following public benefits: environmental conservation and upward social mobility for } \\
\text { low-income communities. }\end{array}$ \\
\hline
\end{tabular}




\begin{tabular}{|c|c|}
\hline $\begin{array}{l}\text { Data.World, } \\
\text { Inc. }\end{array}$ & $\begin{array}{l}\text { Original Certificate (Filed 09/10/2015): } \\
\text { THIRD: The purpose of the Corporation is to engage in any lawful act or activity for } \\
\text { which a corporation may be organized under the General Corporation Law of } \\
\text { Delaware. } \\
\text { Second Amended and Restated Certificate (Filed 07/11/2017): } \\
\text { ARTICLE II } \\
\text { Purpose. The purpose of this Corporation is to engage in any lawful act or activity for } \\
\text { which corporations may be organized under the Delaware General Corporation Law. } \\
\text { Public Benefit Corporation. The Corporation shall be a public benefit corporation as } \\
\text { contemplated by subchapter XV of the Delaware General Corporation Law, or any } \\
\text { successor provisions, that it is intended to operate in a responsible and sustainable } \\
\text { manner and to produce a public benefit or benefits, and is to be managed in a manner } \\
\text { that balances the stockholders' pecuniary interests, the best interests of those } \\
\text { materially affected by the Corporation's conduct and the public benefit or benefits } \\
\text { identified in this Certificate. If the Delaware General Corporation Law is amended to } \\
\text { alter or further define the management and operation of public benefit corporations, } \\
\text { then the Corporation shall be managed and operated in accordance with the Delaware } \\
\text { General Corporation Law, as so amended. } \\
\text { Specific Purposes and Benefits. The specific public benefit purposes of the } \\
\text { Corporation are to (a) strive to build the most meaningful, collaborative and abundant } \\
\text { data resource in the world in order to maximize data's societal problem-solving } \\
\text { utility, (b) advocate publicly for improving the adoption, usability, and proliferation } \\
\text { of open data and linked data, and (c) serve as an accessible historical repository of the } \\
\text { world's data. } \\
\text { To the extent that any provision of this ARTICLE II is found to be invalid or } \\
\text { unenforceable, such invalidity or unenforceability shall not affect the validity or } \\
\text { enforceability of any other provision of this ARTICLE II. }\end{array}$ \\
\hline $\begin{array}{l}\text { Fish+People, } \\
\text { Inc. }\end{array}$ & $\begin{array}{l}\text { (Filed 05/03/2017) } \\
\text { THIRD: } \\
\text { A. The nature of the business of purposes to be conducted or promoted is to } \\
\text { engage in any lawful act or activity for which corporations may be organized under } \\
\text { the General Corporation Law. The purpose of the Corporation shall include creating a } \\
\text { material positive impact on society and the environment, taken as a whole, from the } \\
\text { business and operations of the Corporation. } \\
\text { B. The public benefits to be promoted by the Corporation include the delivery of } \\
\text { nourishing food and supporting the local and global environment. }\end{array}$ \\
\hline $\begin{array}{l}\text { Meow Wolf, } \\
\text { LLC }\end{array}$ & $\begin{array}{l}\text { (Filed 11/26/2016) } \\
\text { ARTICLE THREE: The purpose of the Corporation is to engage in any lawful act or } \\
\text { activity for which corporations may be organized under the General Corporation Law } \\
\text { of the State of Delaware. } \\
\text { ARTICLE FOUR: The Corporation shall be a public benefit corporation as } \\
\text { contemplated by subchapter XV of the Delaware General Corporation Law, or any } \\
\text { successor provisions, that it is intended to operate in a responsible and sustainable } \\
\text { manner and to produce a public benefit or benefit, and is to be managed in a manner } \\
\text { that balances the stockholders pecuniary interests, the best interests of those } \\
\text { materially affected by the Corporation's conduct and the public benefit or benefits } \\
\text { identified in this certificate of incorporation. }\end{array}$ \\
\hline
\end{tabular}




\begin{tabular}{|l|l|}
\hline & $\begin{array}{l}\text { ARTICLE FIVE: As its specific purpose, the Corporation shall employ artists and } \\
\text { creatives to work collaboratively in a sustainable manner to create immersive arts } \\
\text { exhibits and other public oriented innovations. These exhibitions shall seek to provide } \\
\text { positive experiences, economic development, and community betterment. } \\
\text { Furthermore, in order to advance the best interests of those materially affected by the } \\
\text { Corporation's conduct, it is intended that the business and operations of the } \\
\text { Corporation create a material positive impact on society and the environment, taken as } \\
\text { a whole. }\end{array}$ \\
\hline $\begin{array}{l}\text { Global } \\
\text { Uprising, PBC }\end{array}$ & $\begin{array}{l}\text { (Filed 10/02/2013) } \\
\text { ARTICLE III: The purpose of this corporation is to engage in any lawful act or } \\
\text { activity for which a corporation may be organized under the Delaware General } \\
\text { Corporation Law. This corporation shall have a specific public benefit purpose of } \\
\text { using its business to inspire social and environmental change that results in the } \\
\text { improvement of the human condition, increased social consciousness and the } \\
\text { amelioration of poverty. }\end{array}$ \\
\hline
\end{tabular}

\section{$\underline{\text { Public Companies }^{103}}$}

\begin{tabular}{|l|l|}
\hline $\begin{array}{l}\text { Company } \\
\text { Name }\end{array}$ & Statement \\
\hline $\begin{array}{l}\text { Lemonade, } \\
\text { Inc. }\end{array}$ & $\begin{array}{l}\text { (Executed June 25, 2019) } \\
\text { ARTICLE III: The purpose of this corporation is to engage in any lawful act or } \\
\text { activity for which a corporation may be organized under the Delaware General } \\
\text { Corporation Law. }\end{array}$ \\
$\begin{array}{l}\text { Benefit Corporation. This corporation shall be a public benefit corporation as } \\
\text { contemplated by subchapter XV of the Delaware General Corporation Law (the } \\
\text { "DGCL"), or any successor provisions, that it is intended to operate in a responsible } \\
\text { and sustainable manner and to produce a public benefit or benefits, and is to be } \\
\text { managed in a manner that balances the stockholders pecuniary interests, the best } \\
\text { interests of those materially affected by this corporation's conduct and the public } \\
\text { benefit or benefits identified in this certificate of incorporation. Accordingly, it is } \\
\text { intended that the business and operations of this corporation create a material positive } \\
\text { impact on society and the environment, taken as a whole. If the DGCL is amended to } \\
\text { alter or further define the management and operation of public benefit corporations, } \\
\text { then this corporation shall be managed and operated in accordance with the DGCL, as } \\
\text { so amended. }\end{array}$ \\
$\begin{array}{l}\text { Purposes. This corporation's public benefit purpose is to harness novel business } \\
\text { models, technologies and private-nonprofit partnerships to deliver insurance products } \\
\text { where charitable giving is a core feature, for the benefit of communities and their } \\
\text { common causes. The nature of the business or purposes to be conducted or promoted } \\
\text { is to engage in any lawful act or activity for which corporations may be organized } \\
\text { under the General Corporation Law. }\end{array}$ \\
\hline
\end{tabular}

103 Publicly-traded PBCs as of October 1, 2020. 


\begin{tabular}{|c|c|}
\hline $\begin{array}{l}\text { Vital Farms, } \\
\text { Inc. }\end{array}$ & $\begin{array}{l}\text { (Executed 07/05/2020) } \\
\text { THIRD: The nature of the business or purposes to be conducted or promoted by the } \\
\text { Corporation is to engage in any lawful act or activity for which corporations, including } \\
\text { Public Benefit Corporations ("PBCs"), may be organized under the General } \\
\text { Corporation Law of the State of Delaware (the "DGCL"), including without limitation } \\
\text { the following public benefits: (i) bringing ethically produced food to the table; (ii) } \\
\text { bringing joy to our customers through products and services; (iii) allowing crew } \\
\text { members to thrive in an empowering, fun environment; (iv) fostering lasting } \\
\text { partnerships with our farmers and suppliers; (v) forging an enduring profitable } \\
\text { business; and (vi) being stewards of our animals, land, air, and water, and being } \\
\text { supportive of our community. }\end{array}$ \\
\hline $\begin{array}{l}\text { Laureate } \\
\text { Education, } \\
\text { Inc. }\end{array}$ & $\begin{array}{l}\text { Executed 01/2017) } \\
\text { ARTICLE II: The purpose of the Corporation is to engage in any lawful act or activity } \\
\text { for which a corporation may be organized under the DGCL. The specific public } \\
\text { benefit purpose of the Corporation is to produce a positive effect (or a reduction of } \\
\text { negative effects) for society and persons by offering diverse education programs } \\
\text { delivered online and on premises operated in the communities that we serve, as the } \\
\text { board of directors may from time to time determine to be appropriate and within the } \\
\text { Corporation's overall education mission. }\end{array}$ \\
\hline $\begin{array}{l}\text { Veeva } \\
\text { Enterprises, } \\
\text { Inc. }\end{array}$ & $\begin{array}{l}\text { (Executed 02/01/2021) } \\
\text { The Corporation shall be a public benefit corporation, as contemplated by subchapter } \\
\text { XV of the DGCL, and is to be managed in a manner that balances our stockholders' } \\
\text { pecuniary (financial) interests, the best interests of those materially affected by the } \\
\text { corporation's conduct (including customers, employees, partners, and the communities } \\
\text { in which we operate), and the public benefits identified in this certificate of } \\
\text { incorporation. We believe this corporate structure reflects our guiding principle, "do } \\
\text { the right thing." The specific public benefits to be promoted by the Corporation are to } \\
\text { provide products and services that are intended to help make the industries we serve } \\
\text { more productive, and to create high-quality employment opportunities in the } \\
\text { communities in which we operate }\end{array}$ \\
\hline
\end{tabular}

